Article

\title{
Hydrological Simulation and Runoff Component Analysis over a Cold Mountainous River Basin in Southwest China
}

\author{
Weidong Xuan ${ }^{1}$, Qiang Fu ${ }^{2}$, Guanghua Qin ${ }^{3}$, Cong Zhu ${ }^{2}$, Suli Pan ${ }^{1}$ and Yue-Ping Xu ${ }^{1, *}$ \\ 1 Institute of Hydrology and Water Resources, Civil Engineering, College of Civil Engineering and \\ Architecture, Zhejiang University, Zhejingang Campus, Yuhangtang Road \#866, Hangzhou 310058, China; \\ london@zju.edu.cn (W.X.); pansuli@zju.edu.cn (S.P.) \\ 2 Hydrochina Huadong, Hangzhou 311122, China; fu_q@ecidi.com (Q.F.); zhu_c@ecidi.com (C.Z.) \\ 3 School of Water Resources and Hydropower, Sichuan University, Chengdu 610065, China; \\ ghqin2000@163.com \\ * Correspondence: yuepingxu@zju.edu.cn
}

Received: 30 October 2018; Accepted: 16 November 2018; Published: 21 November 2018

check for updates

\begin{abstract}
Assessment of water resources from mountainous catchments is crucial for the development of upstream rural areas and downstream urban communities. However, lack of data in these mountainous catchments prevents full understanding of the response of hydrology or water resources to climate change. Meanwhile, hydrological modeling is challenging due to parameter uncertainty. In this work, one tributary of the Yarlung Zangbo River Basin (the upper stream of the Brahmaputra River) was used as a case study for hydrological modeling. Tropical Rainfall Measuring Mission (TRMM 3B42V7) data were utilized as a substitute for gauge-based rainfall data, and the capability of simulating precipitation, snow, and groundwater contributions to total runoff by the Soil and Water Assessment Tool (SWAT) was investigated. The uncertainty in runoff proportions from precipitation, snowmelt, and groundwater was quantified by a batch-processing module. Hydrological signatures were finally used to help identify if the hydrological model simulated total runoff and corresponding proportions properly. The results showed that: (1) TRMM data were very useful for hydrological simulation in high and cold mountainous catchments; (2) precipitation was the primary contributor nearly all year round, reaching $56.5 \%$ of the total runoff on average; (3) groundwater occupied the biggest proportion during dry seasons, whereas snowmelt made a substantial contribution only in late spring and summer; and (4) hydrological signatures were useful for helping to evaluate the performance of the hydrological model.
\end{abstract}

Keywords: SWAT; TRMM 3B42V7; Niyang River Basin; runoff component analysis

\section{Introduction}

Water is the origin of life, the necessity of industrial manufacturing, and the foundation of ecology. Nowadays, human-induced changes such as climate change, population growth, and rapid urbanization are putting enormous stress on water resources. Besides, the energy crisis has wrapped around the globe, and it is acknowledged that hydroelectric power generation is a better choice than other traditional energy means as it produces less pollution [1]. Increasing demands for fresh water for living and manufacturing also lead to critical water resource shortage, which requires sophisticated water resource management [2,3]. The southwestern area of China, which is also called the "Chinese water tower" or "Asian water tower", provides $49 \%$ of the runoff for the Yellow River. The exit flow of the Yarlung Zangbo River, the Lantsang River, and the Salween River aggregately come to 500 billion cubic meters, which is nearly equal to the total water consumption of China (600 billion 
cubic meters) [4]. Current per capita availability of water in China is only equal to one-fourth of the world. Water shortage becomes more severe along with climate change and developments in economics. The southwest source area is the forming region and strategic stockpile for fresh water for China and will certainly play an important role in future water management.

Precipitation is the most important driving factor for hydrological cycles. It is nearly impossible for hydrologists to simulate the water cycles over regions with no or sparse precipitation gauge networks [5]. Without the observed data to force hydrological models, it is hard to conduct calibrations of model parameters, and the output of models is doubtful. In fact, the availability of high-quality ground rainfall data is very limited across many parts of the world, especially over complex terrain and remote areas. Currently there are many satellite precipitation products, such as the Tropical Rainfall Measuring Mission (TRMM) Multisatellite Precipitation Analysis (TMPA) [6], the National Oceanic and Atmospheric Administration (NOAA) Climate Prediction Center (CPC) MORPHing technique product [7], the Precipitation Estimation from Remotely Sensed Information using Artificial Neural Networks (PERSIANN) [8], and the PERSIANN Cloud Classification System estimation [9]. These satellite precipitation products provide alternatives for gauge precipitation, which have experienced significant success in the past decade. Satellite rainfall data were compared from PERSIANN, TMPA-3B42V7, and TMPA-3B42RT, as well as with gauged data over Iran, which showed that TMPA-3B42V7 behaved better than the other two [10]. CMORPH, PERSIANN, TRMM-3B42V7, and TRMM 3B43 were compared to ground data in the arid region of China, which showed that TRMM 3B42V7 performed the best in detecting precipitation occurrences and accessing precipitation amount [11]. PERSIANN-CDR, TRMM-3B42V7, and (National Centers for Environment Prediction-Climate Forecast System Reanalysis) NCEP-CFSR were evaluated against gauge observations in two humid basins of China, which showed that TRMM-3B42V7 outperformed the other two products, with the smallest errors and bias and the highest correlation on a monthly scale: Besides, simulations forced with 3B42V7 achieved the best match with daily gauged streamflow [12]. Therefore, in this study, TRMM-3B42V7 data were used. The Tropical Rainfall Measuring Mission is a mission that delivers a unique 17-year dataset of global tropical rainfall to improve understanding of climate and weather modeling, human impacts on rainfall, snow and snowmelt modeling, among other endeavors [13-20]. The TRMM 3B42V7 is a product from the TRMM Multisatellite Precipitation Analysis, which is based on the calibration by the TRMM Combined Instrument and TRMM Microwave Imager precipitation products. The 3B42V7 incorporates the new Global Precipitation Climatology Centre monthly precipitation for bias adjustment [12].

Runoff component analyses are important in hydrological studies. However, very limited attention has been paid to proper simulations of runoff components when using hydrological models [21]. Most studies have only investigated whether the hydrological models used in the applications simulate the total runoff reasonably in the calibration or validation [22-25]. However, only considering the total runoff in the calibration or validation may cause errors in prediction or forecasting, particularly in areas where snow or glaciers contribute significantly to the total runoff. The results seem to be satisfactory based on the first sight of objective function values like the Nash efficiency coefficient (NS) and relative bias (PBIAS) obtained in the calibration [22]. However, precipitation, snowmelt, and groundwater components of runoff may deviate from reality, which probably results in wrong predictions or projections. This can be due to the fact that only limited observation data are often available for hydrological modeling. Recently, a few studies did pay attention to this problem. For example, a degree-day-based distributed hydrological model was used to investigate the spatial distribution of runoff components in the Koxkar Glacier, which could reveal characteristics of climatic gradients, local topography and morphology, and catchment meteorology [26]: Path analysis was utilized along with isotopic measurements to investigate runoff components in a glacier-covered alpine catchment (the upper Hailuogou Valley) in southwest China and revealed that snowmelt took up nearly three quarters of total discharge [27]. The study here will provide good insight into hydrological modeling by investigating runoff proportions in-depth over a cold mountainous river basin with very 
limited data. There will be more confidence in hydrological modeling based on deeper investigation into runoff components.

Besides runoff component analysis, hydrological signatures could be alternatives in identifying if the hydrological model simulates runoff components properly. Hydrological signatures have been widely used in evaluating hydrological model and streamflow characteristics such as overall water balance, vertical soil moisture redistribution, behavior of long-term baseflow, and timing. Therefore, hydrological signature analysis can be the supplement to residual-based goodness-of-fit measures, (e.g., the Nash-Sutcliffe efficiency measure) [28-31]. In this study, hydrological signatures were used to support the analysis of total runoff and corresponding components.

A tributary of the Yarlung Zangbo River, namely the Niyang River, where the in situ observation was rather limited, was selected as the case study. The objective of this work was two-fold: (1) To testify as to whether TRMM-3B42V7 was suitable for hydrological modeling in complex terrain in the southwest of China, and (2) to analyze the proportions of different runoff components from precipitation, groundwater, and snow in the selected basin. The paper is organized as follows: Section 2 introduces the study area and data. Section 3 describes the main methodology, including precipitation evaluation indices, hydrological model, and hydrological signatures. Results are presented in Section 4. Finally, discussion and conclusions are described in Sections 5 and 6.

\section{Study Area and Data}

\subsection{Study Area}

Due to enormous differences in height and latitude, there are various climatic zones in Tibet, including humid tropical or subtropical zones, semi-humid (or semi-arid) temperate zones, and semi-arid (or arid) cold zones. The study area, the Niyang River Basin, is located in a humid temperate climate zone. Figure 1 shows the location of the study area. The Niyang River originates from the west of Mila Mountain and joins with the Yarlung Zangbo River in Linzhi County. The average temperature is about 8 degrees centigrade, with an annual precipitation of $600-900 \mathrm{~mm}$ and annual sunshine duration of $2022 \mathrm{~h}$. The river is $307.5 \mathrm{~km}$ in length, and the basin area is $16,048.7 \mathrm{~km}^{2}$. The average slope of the river is $7.39 \%$. The elevation of the basin ranges from $3055 \mathrm{~m}$ to $6760 \mathrm{~m}$ in height. The main rainy season is from June to September, and more than $90 \%$ of discharge comes from this season. The river is abundant in water resources, 22 billion cubic meters per year, and ranks as the fourth-largest among all tributaries of the Yarlung Zangbo River. However, annual change of runoff in Niyang River is not substantial. Also, historical data and literature show that temperature is increasing and will probably continue to increase in the future: Precipitation in the Niyang River Basin will probably increase to some degree [3,4]. 


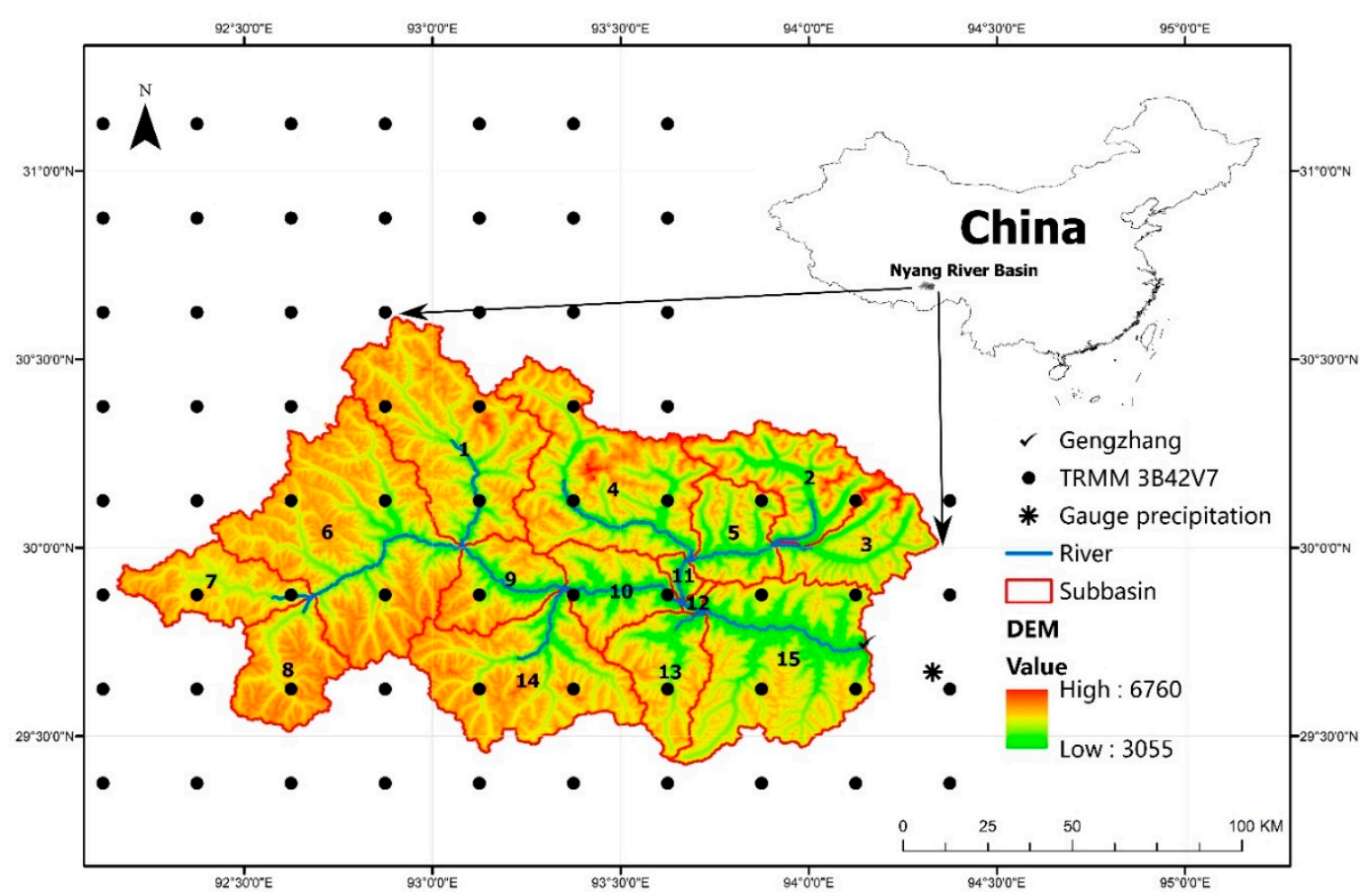

Figure 1. Location of the study area and spatial distribution of data used in the Soil and Water Assessment Tool (SWAT) model.

\subsection{Data}

The spatial distribution of precipitation grid points and gauge stations used in this study are illustrated in Figure 1. Meteorological observations in the study area were very limited. Daily meteorological observations (maximum and minimum temperature, relative humidity, wind speed, and solar radiation) from 1978 to 2013 at one nearby station, namely Linzhi Station, were obtained from the China Meteorological Administration. There were no meteorological observations in higher areas of the basin. The available daily discharge record at Gengzhang Station was from 1978 to 2011, with missing data in 2009. Besides observed meteorological data at Linzhi, the Tropical Rainfall Measuring Mission was used for precipitation alternatives. The resolution of TRMM 3B42V7 was $0.25 \times 0.25^{\circ}$.

Digital elevation model (DEM) data at $90 \mathrm{~m}$ were downloaded from the Geospatial Data Cloud (http:/ / www.gscloud.cn). Soil data with a $1 \mathrm{~km}$ resolution were obtained from the Environment and Ecological Science Data Center for West China, National Natural Science Foundation of China (http:/ / westdc.westgis.ac.cn). Land use data with a resolution of $1 \mathrm{~km}$ were downloaded from Global Land Cover 2000 (http:/ / bioval.jrc.ec.europa.euproducts/glc2000/products).

\section{Methodology}

The framework of this study is shown in Figure 2. First, the TRMM 3B42V7 precipitation was evaluated against the observation to check its performance in the study area. Second, TRMM 3B42V7 was utilized to drive the Soil and Water Assessment Tool (SWAT) hydrological model. A batch-processing module was proposed in this study to automatically perform multiple simulations from SWAT. Behavior hydrological model parameters were used to analyze the runoff components by selecting those with NS $>0.5$ and within $\pm 20 \%$ PBIAS. Finally, hydrological signatures concerning mean, low, and high flows were computed to verify the runoff components calculated based on hydrological simulations driven by TRMM 3B42V7. 


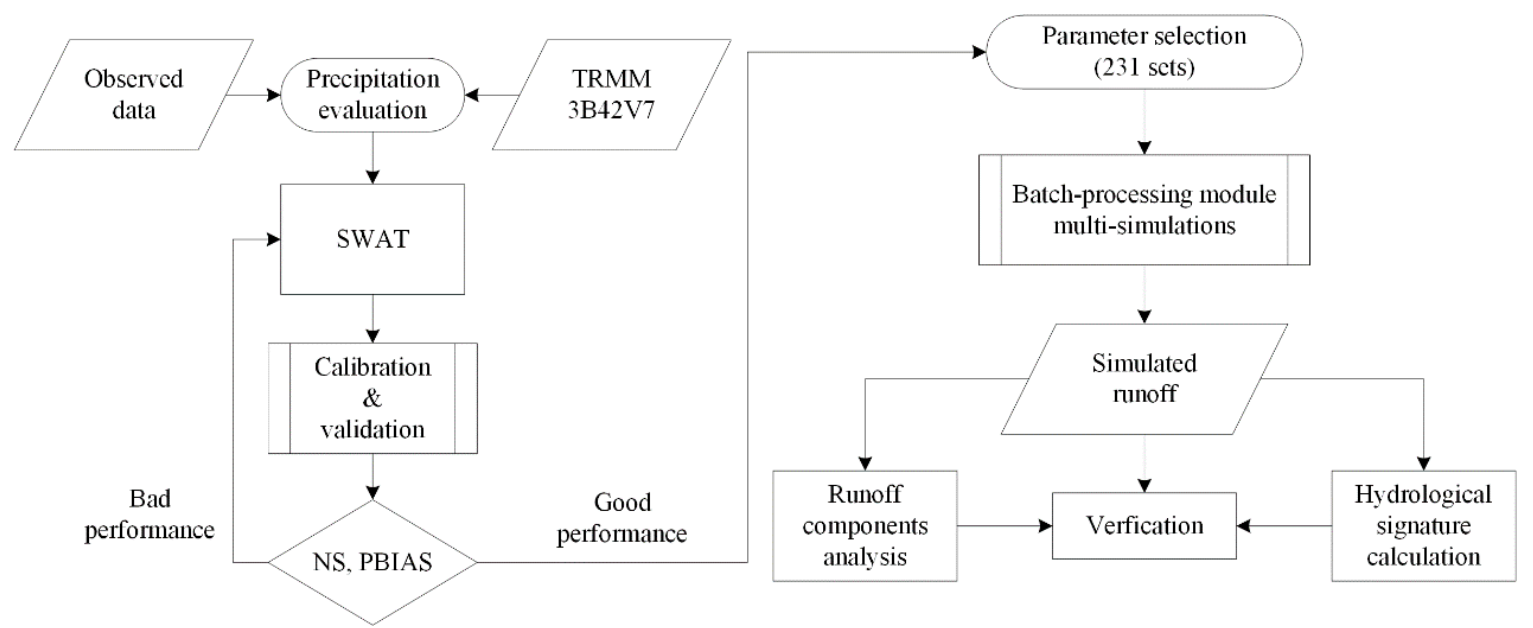

Figure 2. Framework of this study.

\subsection{Precipitation Evaluation Indices}

Although observed precipitation data were available for only one nearby station, such data were still used here to help evaluate the appropriateness of TRMM data in hydrological modeling. Two statistical indices were used for the evaluation, namely correlation coefficient (CC) and root mean squared error (RMSE) [32]. CC reflects the degree of linear correlation between precipitation products and gauge observations. RMSE measures the average error between the precipitation estimates and observations, with greater weight on the larger errors.

\subsection{Hydrological Model}

SWAT is a river basin or watershed scale model developed by Dr. Jeff Arnold for the United States Department of Agriculture (USDA) Agricultural Research Service [23,33]. SWAT was developed to predict the impact of land management practices on water, sediment, and agricultural chemical yields in large complex watersheds with varying soils, land use, and management conditions over long periods of time. The SWAT model has the following characteristics: It is physically based, uses readily available inputs, and is computationally efficient. Also, SWAT allows a number of different physical processes to be simulated in a watershed. For modeling purposes, a watershed may be partitioned into a number of subwatersheds or sub-basins. Hydrologic response units are lumped land areas within the sub-basin that are comprised of unique land cover, soil, and management combinations. In this study, the basin was delineated into 15 sub-basins and further into 172 hydrologic response units (HRUs), and the size of the HRUs ranged from $0.84 \mathrm{~km}^{2}$ to $913.26 \mathrm{~km}^{2}$.

In the SWAT model, water balance is the driving force behind everything that happens in the watershed. The hydrologic cycle simulated by SWAT is based on the following water balance equation:

$$
S W_{t}=S W_{0}+\sum_{i=1}^{t}\left(R_{\text {day }}-Q_{\text {surf }}-E_{a}-w_{\text {seep }}-Q_{g w}\right),
$$

where $S W_{t}$ is the final soil water content (in $\mathrm{mm} \mathrm{H}_{2} \mathrm{O}$ ), $S W_{0}$ is the initial soil water content on day $i$ (in $\mathrm{mm} \mathrm{H}_{2} \mathrm{O}$ ), $t$ is the time (in days), $R_{\text {day }}$ is the amount of precipitation on day $i$ (in $\mathrm{mm}_{2} \mathrm{O}$ ), $Q_{\text {surf }}$ is the amount of surface runoff on day $i$ (in $\mathrm{mm} \mathrm{H}_{2} \mathrm{O}$ ), $E_{a}$ is the amount of evapotranspiration on day $i$ (in $\mathrm{mm} \mathrm{H}_{2} \mathrm{O}$ ), $w_{\text {seep }}$ is the amount of water entering the vadose zone from the soil profile on day $i$ (in $\mathrm{mm} \mathrm{H}_{2} \mathrm{O}$ ), and $Q_{g w}$ is the amount of return flow on day $i$ (in $\mathrm{mm} \mathrm{H}_{2} \mathrm{O}$ ).

The main sources of uncertainty in hydrological modeling are: (1) Simplifications in the conceptual model, (2) processes occurring in the watershed but not included in the model, (3) processes that are included in the model, but their occurrences in the watershed are unknown to the modeler or unaccountable, (4) processes that are not known to the modeler and not included in the model, 
and (5) errors in the input variables such as rainfall and temperature [34]. Besides errors in input variables, uncertainty in parameters for modeling hydrological processes is important. Therefore, before calibration, parameter sensitivity analysis is essential to provide insights on which parameters contribute most to the output variance because of input variability [35]. Here, 21 hydrological parameters were used for sensitivity analysis for the simulation of streamflow in the study area. The details of all hydrological parameters can be found in Reference [36].

The calibration and uncertainty analysis was done via sequential uncertainty fitting method (SUFI-2). SUFI-2 is the calibration algorithm developed for the calibration of the SWAT model [37]. In SUFI-2, the degree to which all uncertainties are accounted for is quantified by the $p$-factor and $r$-factor. The $p$-factor is the percentage of measured data enveloped by the $95 \%$ probability distribution (95PPU). The $r$-factor is the average thickness of the 95PPU. The 95PPU is calculated at the $2.5 \%$ and $97.5 \%$ levels of the cumulative distribution of an output variable generated by the propagation of the parameter uncertainties using Latin hypercube sampling [28].

NS and PBIAS were used to evaluate the performance of the hydrological model [22]. NS is a normalized statistic that determines the relative magnitude of the residual variance compared to the measured data variance, and it indicates how well the plot of observed versus simulated data fits the 1:1 line. PBIAS measures the average tendency of the simulated data to be larger or smaller than their observed counterparts. The optimal value of PBIAS is 0 , with low-magnitude values indicating accurate model simulation. Positive values indicate model underestimation bias, and negative values indicate model overestimation bias [38].

After calibration, parameter sets with an NS value larger than 0.5 and a PBIAS value within $\pm 20 \%$ are regarded as the behavior parameters for the SWAT model [39]. Since the original SWAT model only delivered output files for single simulation, a batch-processing module was developed in this study to conduct SWAT simulations automatically as well as to store the output files of each simulation for further component analysis. Based on this, multisimulations were again conducted by the batch-processing module to obtain detailed information on the runoff components (runoff proportions) for all behavior parameter sets. Such a procedure was implemented for TRMM-driven hydrological simulation.

\subsection{Runoff Components and Hydrological Signatures}

Basin conditions, especially climatic factors, have much influence on the river discharge. Precipitation, temperature, and evapotranspiration vary greatly in space. All these factors deeply influence the formation as well as the evolution of runoff. In the Niyang River Basin, precipitation, snow, and groundwater are equally important in generating total runoff in the river outlet. However, their detailed contributions are not clearly quantified. This is particularly important when climate change is affecting the mountainous river, and snow may melt due to temperature increase.

In this study, the SWAT model was used for analysis of the runoff component. Compared to traditional methods of runoff component analysis such as isotope and pathway analysis [27], hydrological modeling requires much less field experimentation, which costs time and resources. Based on the structure of the SWAT model, runoff components can only be calculated at the HRU level and then summed at the sub-basin/watershed level. In this study, irrigation water and ponds and reservoirs were not taken into consideration. Streamflow was composed of three components: Rain-generated, snowmelt, and groundwater flow. Groundwater contributed to streamflow from both aquifers and could be directly obtained from model outputs. TRMM 3B42V7 provided original precipitation, which was further divided into rain and snow via the SWAT model based on a snowfall temperature parameter (SFTMP). Thus, initial volumes of rain and snowmelt were available in the model to help determine their respective proportions in remaining streamflow. The equations are listed below:

$$
f_{Q, G}=\frac{G}{Q^{\prime}}
$$




$$
\begin{aligned}
& f_{Q, R}=\frac{R}{R+S}\left(1-f_{Q, G}\right), \\
& f_{Q, S}=\frac{S}{R+S}\left(1-f_{Q, G}\right),
\end{aligned}
$$

where $f_{Q, G}$ represents the fraction of total runoff that originated from groundwater, $G$ is groundwater contribution to total runoff, $Q$ is the total runoff, $f_{Q, R}$ represents the fraction of total runoff that originated from rainfall, $R$ is the amount of precipitation falling as rainfall, $S$ is the amount of snowmelt obtained from the SWAT model, and $f_{Q, S}$ represents the fraction of total runoff that originated from snowmelt.

Hydrological signatures are a number of important streamflow characteristics that constitute the natural flow regimes, including seasonal pattern of flows; timing of extreme flows; frequency, predictability, and duration of floods, droughts, and intermittent flows; daily, seasonal, and annual flow variability; and rates of change. They can be used as alternatives to investigate whether runoff components are properly simulated in hydrological modeling. In this study, five hydrological signatures (see Table 1) concerning annual mean, minimum, and maximum monthly flows were selected to help evaluate whether the total runoff and corresponding components were simulated well by the hydrological model with TRMM 3B42V7.

\begin{tabular}{|c|c|c|c|c|}
\hline Hydrological Signature & Code & Unit & Conditions & Definition \\
\hline Mean annual runoff & A1 & $\mathrm{m}^{3} \mathrm{~s}^{-1} \mathrm{~km}^{-2}$ & $\begin{array}{l}\text { Average flow } \\
\text { conditions }\end{array}$ & $\begin{array}{l}\text { Mean annual divided by } \\
\text { catchment area }\end{array}$ \\
\hline $\begin{array}{l}\text { Mean minimum } \\
\text { monthly flows }\end{array}$ & ML1-12 & $\mathrm{m}^{3} \mathrm{~s}^{-1}$ & $\begin{array}{l}\text { Low flow } \\
\text { conditions }\end{array}$ & $\begin{array}{l}\text { Mean minimum monthly } \\
\text { flow for all months }\end{array}$ \\
\hline $\begin{array}{c}\text { Variability across } \\
\text { minimum monthly flows }\end{array}$ & ML13 & $\%$ & $\begin{array}{l}\text { Low flow } \\
\text { conditions }\end{array}$ & $\begin{array}{l}\text { Coefficient of variation in } \\
\text { minimum monthly flows }\end{array}$ \\
\hline $\begin{array}{l}\text { Mean maximum } \\
\text { monthly flows }\end{array}$ & MH1-12 & $\mathrm{m}^{3} \mathrm{~s}^{-1}$ & $\begin{array}{l}\text { High flow } \\
\text { conditions }\end{array}$ & $\begin{array}{l}\text { Mean of the maximum } \\
\text { monthly flows for } \\
\text { all months }\end{array}$ \\
\hline $\begin{array}{l}\text { Variability across } \\
\text { maximum } \\
\text { monthly flows }\end{array}$ & MH13 & $\%$ & $\begin{array}{l}\text { High flow } \\
\text { conditions }\end{array}$ & $\begin{array}{l}\text { Coefficient of variation in } \\
\text { maximum monthly flows }\end{array}$ \\
\hline
\end{tabular}

Table 1. Hydrological signatures utilized in the study.

\section{Results}

\subsection{Precipitation Evaluation Results}

Since the in situ observation of precipitation was very limited, only two evaluation indices were calculated based on areal mean precipitation of the basin. For the observation, gauge data were used to approximate the areal mean precipitation. A Thiessen polygon was used to generate the areal mean precipitation of TRMM 3B42V7. The results showed that on a daily scale, TRMM 3B42V7 had poor correlations (0.4) with observation. However, there were much better correlations (0.9) on a monthly scale. Besides, the value of the RMSE on a daily scale $(53 \mathrm{~mm})$ was almost 2 times the monthly value $(35 \mathrm{~mm})$. If observation and the nearest grid point of TRMM were compared, on a daily scale TRMM 3B42V7 also had poor correlations (0.4), whereas there were much better correlations (0.9) on a monthly scale. The value of the RMSE on a daily scale $(5 \mathrm{~mm})$ was more than 3 times that of the monthly value $(1.4 \mathrm{~mm})$. The results based on the neatest grid were better than those based on the areal mean values. Since the observation data obtained were too limited, the evaluation results of TRMM data may not mean a lot, only indicating to some extent the quality of the TRMM data. Based on both evaluation results, the simulation of the hydrological model was made on a monthly scale. 


\subsection{Hydrological Model Calibration and Validation}

TRMM 3B42V7 was used to drive SWAT to obtain monthly discharge. The investigation period was divided into three parts, namely the warm-up period from 1998 to 1999, the calibration period from 2000 to 2008, and the validation period from 2010 to 2011.

In this study, sensitivity analysis was accomplished with the Latin hypercube and the one factor at a time sampling method [40]. The most sensitive parameters are listed in Table 2. Since there were no good references for parameter ranges for SWAT hydrological simulations in the study area, default initial parameter ranges from the model were used. A multiple regression analysis was used in SWAT to get the statistics of parameter sensitivity, and $p$-values for corresponding parameters were calculated. A $p$-value tests the null hypothesis that the coefficient is equal to zero (no effect), and it ranges from 0 to 1 . A large $p$-value suggests that changes in the predictor are not associated with changes in the response, which means that parameter is not very sensitive [41]. After two iterations, rational parameter ranges were obtained with reasonable values of objective functions. It is worth paying attention to lapse rates of temperature and precipitation [42]. The $p$-values of both lapse rates were almost equal to 0 , which means the change of precipitation and temperature with elevation had enormous influence on runoff.

Table 2. Parameters used in SWAT model, and their ranges used in calibration.

\begin{tabular}{ccccc}
\hline Code $^{\mathbf{a}}$ & Parameter & Description & Unit & Initial Range \\
\hline 1 & TLAPS $^{\mathrm{v}}$ & Temperature lapse rate & ${ }^{\circ} \mathrm{C} \mathrm{km}$ & {$[-10,0]$} \\
2 & PLAPS $^{\mathrm{v}}$ & Precipitation lapse rate & $\mathrm{mm} / \mathrm{km}$ & {$[-3,3]$} \\
3 & CN2 $^{\mathrm{a}}$ & SCS runoff curve number for moisture condition 2 & - & {$[-57,73]$} \\
4 & SMTMP $^{\mathrm{v}}$ & Snow melt base temperature & ${ }^{\circ} \mathrm{C}$ & {$[-5,5]$} \\
5 & SOL_Z $^{\mathrm{r}}$ & Depth from soil surface to bottom of layer & $\mathrm{mm}$ & {$[-0.9,150]$} \\
\hline
\end{tabular}

a Parameters with smaller codes indicate greater sensitivity. Three types of change were applied to the parameters: ${ }^{v}$ means the existing parameter value was replaced by the given value, ${ }^{a}$ means the given value was added to the existing parameter value, and ${ }^{\mathrm{r}}$ means the existing parameter value was multiplied by ( $1+$ a given value). SCS (Soil Conservation Service).

Two iterations were conducted to derive reasonable $r$-factor and $p$-factor values, which were 1.35 and $97 \%$, respectively. Considering the shortage of gauged precipitation and temperature data (only one nearby meteorological station had access to temperature data), the values of two indices were regarded as reasonable. The corresponding distributions of NS and PBIAS of the second iteration are shown in Figure 3, and all values of behavior parameter sets met the standards of reasonable simulation [39]. The red bold cross represents the "best" calibration parameter set, whose value of NS was 0.89 and whose value of PBIAS was $2.8 \%$. Figure 4 shows the observed and simulated total runoff as well as the precipitation time series during calibration and validation. It can be observed that the observation data was well-enveloped by the 95PPU range except for during the first year. However, there were some deviations for extreme flows, especially peak flows, which were somehow the inherent disadvantage of the SWAT model [22]. 


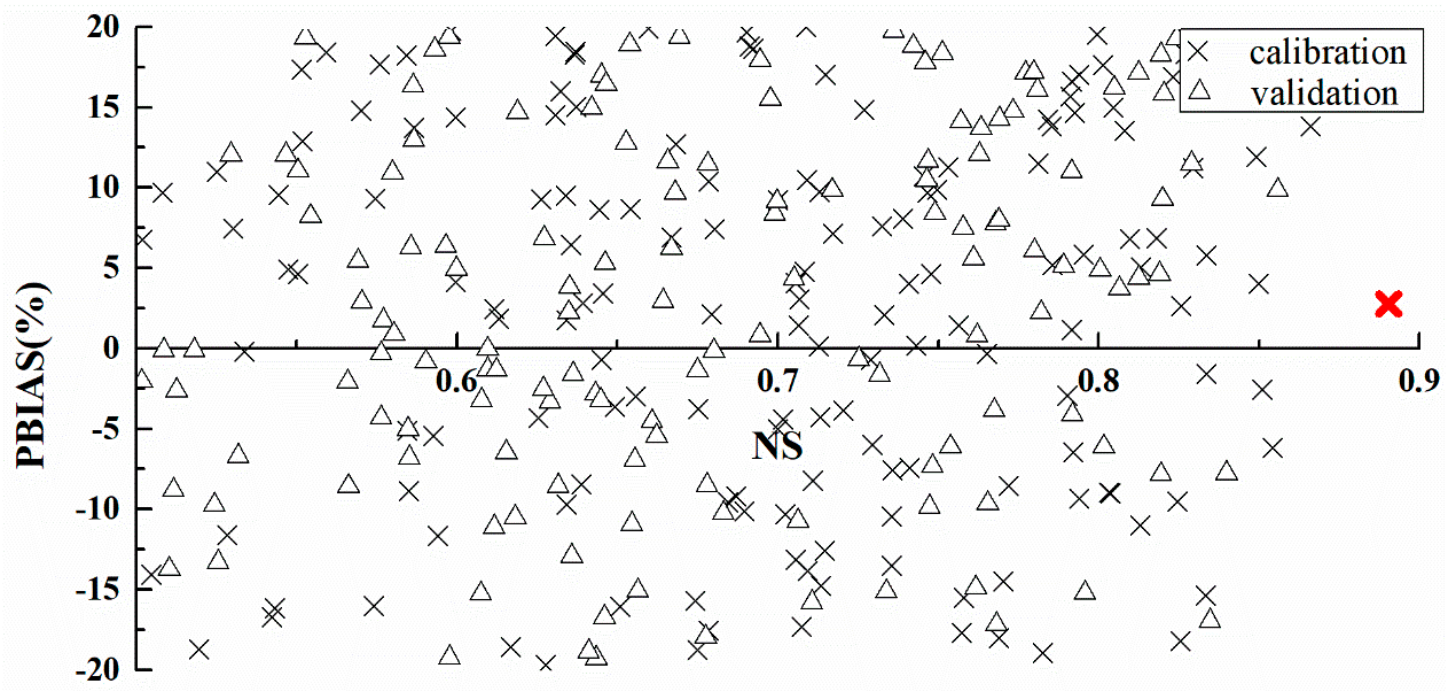

Figure 3. Distributions of NS and PBIAS achieved via a batch-processing module driven by Tropical Rainfall Measuring Mission (TRMM) 3B42V7.

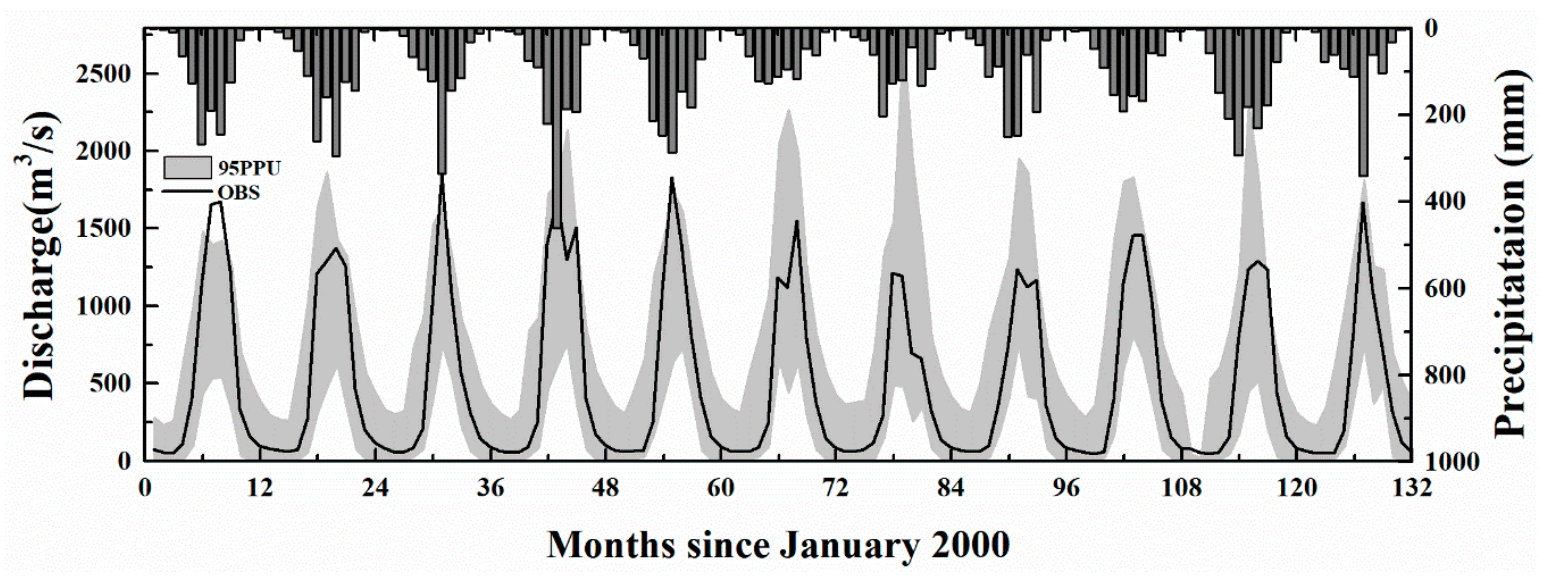

Figure 4. Observed and simulated total runoff and precipitation during calibration and validation.

\subsection{Runoff Component Analysis}

Due to parameter equifinality in hydrological modeling, here the batch-processing module was developed to obtain runoff components of all behavior parameter sets (for which the number was 231). One parameter set was regarded as the "reference" (traditionally the best one), with the highest NS value, 0.89 , and a reasonable PBIAS value of $2.8 \%$.

Figure 5 shows the proportion of runoff components from 2000 to 2011 derived from the behavior simulations based on TRMM 3B42V7. It shows that precipitation was the dominating contributor to the total runoff, reaching $56.5 \%$ on average. Groundwater contribution ranked second $(28.3 \%)$, and snowmelt contributed the least $(15.2 \%)$.

During the calibration period, proportions of precipitation showed less volatility, ranging from $52 \%$ to $59 \%$, of which the fluctuations were within $7 \%$ and the average was $55 \%$. Proportions of snowmelt ranged from $13 \%$ to $17 \%$, with fluctuations of about $5 \%$, and the average was $15 \%$. As for groundwater, proportions ranged from $27 \%$ to $32 \%$, and the fluctuations were rather small. Three components distributed evenly through the calibration period. As for the validation period, proportions of precipitation ranged from $60 \%$ to $68 \%$, and the average was $64 \%$. Proportions of snowmelt ranged from $17 \%$ to $20 \%$, and the average was $18 \%$. Proportions of groundwater ranged from $13 \%$ to $23 \%$, and the average was $18 \%$. 


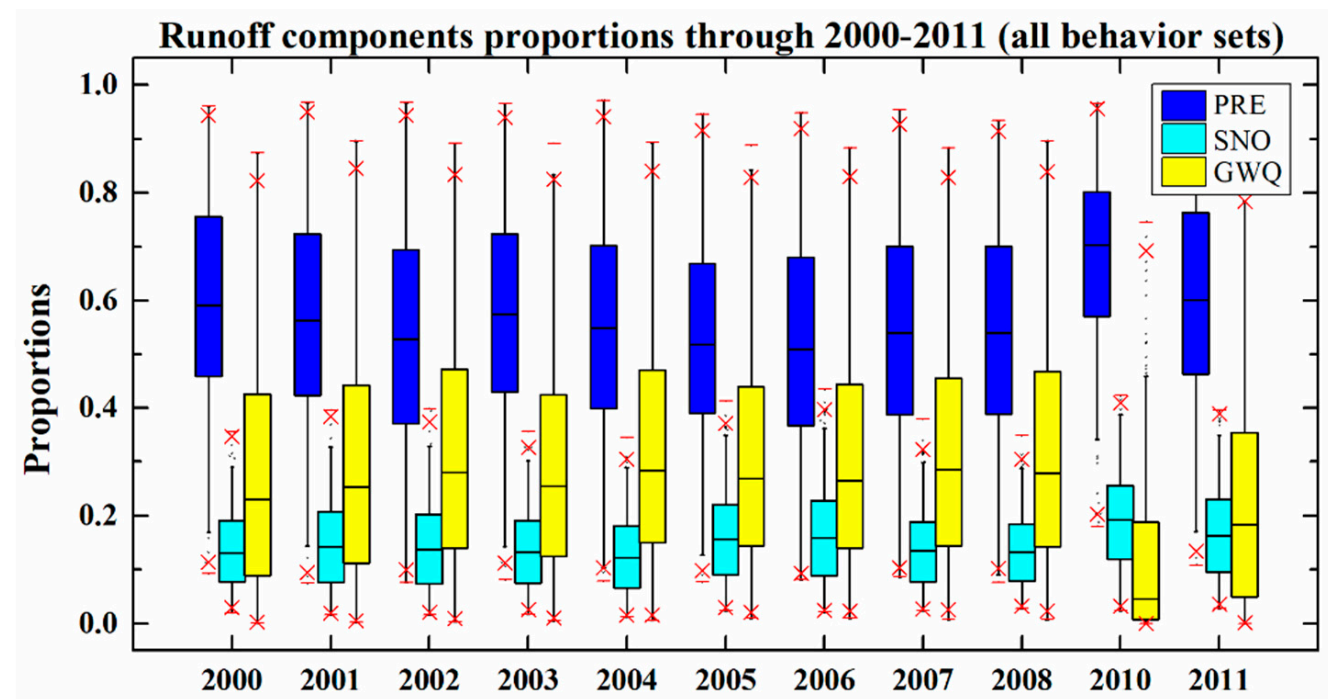

Figure 5. Proportions of runoff components from 2000 to 2011 derived from behavior simulations based on TRMM 3B42V7. GWQ stands for groundwater runoff, SNO stands for snowmelt runoff, and PRE stands for rainfall runoff. The red crosses wrap $98 \%$ of all data. The red short lines represent maximum and minimum values of all data. Black dots are outliners.

Figure 6 shows monthly distributions of runoff components from 2000 to 2011, derived from simulations based on TRMM 3B42V7 for all behavior simulations. Seasonal patterns can be witnessed for three components: Rain-induced runoff took the dominant place during wet seasons (from June to September) and occupied more than half of total runoff, and groundwater runoff came in first place during dry seasons (from December to March). For snowmelt, there was seasonal tendency, too. Snowmelt runoff arose from March to May, and then decreased to zero from May to October. The peak rate occurred in early summer.

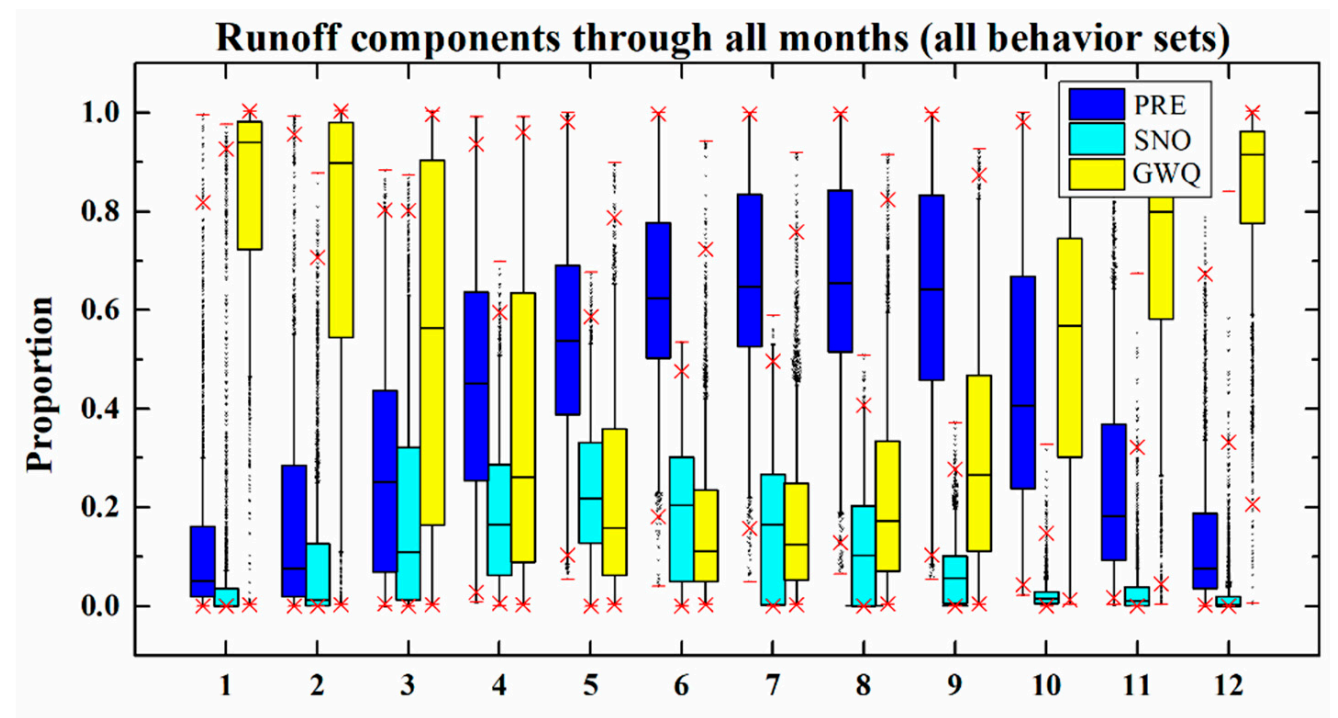

Figure 6. Monthly distribution of runoff components from 2000 to 2011, derived from simulations based on TRMM 3B42V7 for all behavior simulations.

\subsection{Hydrological Signatures}

In this section, hydrological signatures were used to help verify if the total runoff and corresponding components were properly simulated by the hydrological model. Signatures shown in Table 1 were computed based on monthly runoff driven by TRMM 3B42V7. Figure 7 shows the 
hydrological signatures derived from the observed and simulated runoff based on TRMM 3B42V7. Table 3 presents the hydrological signatures derived from the observed discharge as well as the upper and lower boundary of 95PPU of all behavior simulations based on TRMM 3B42V7.
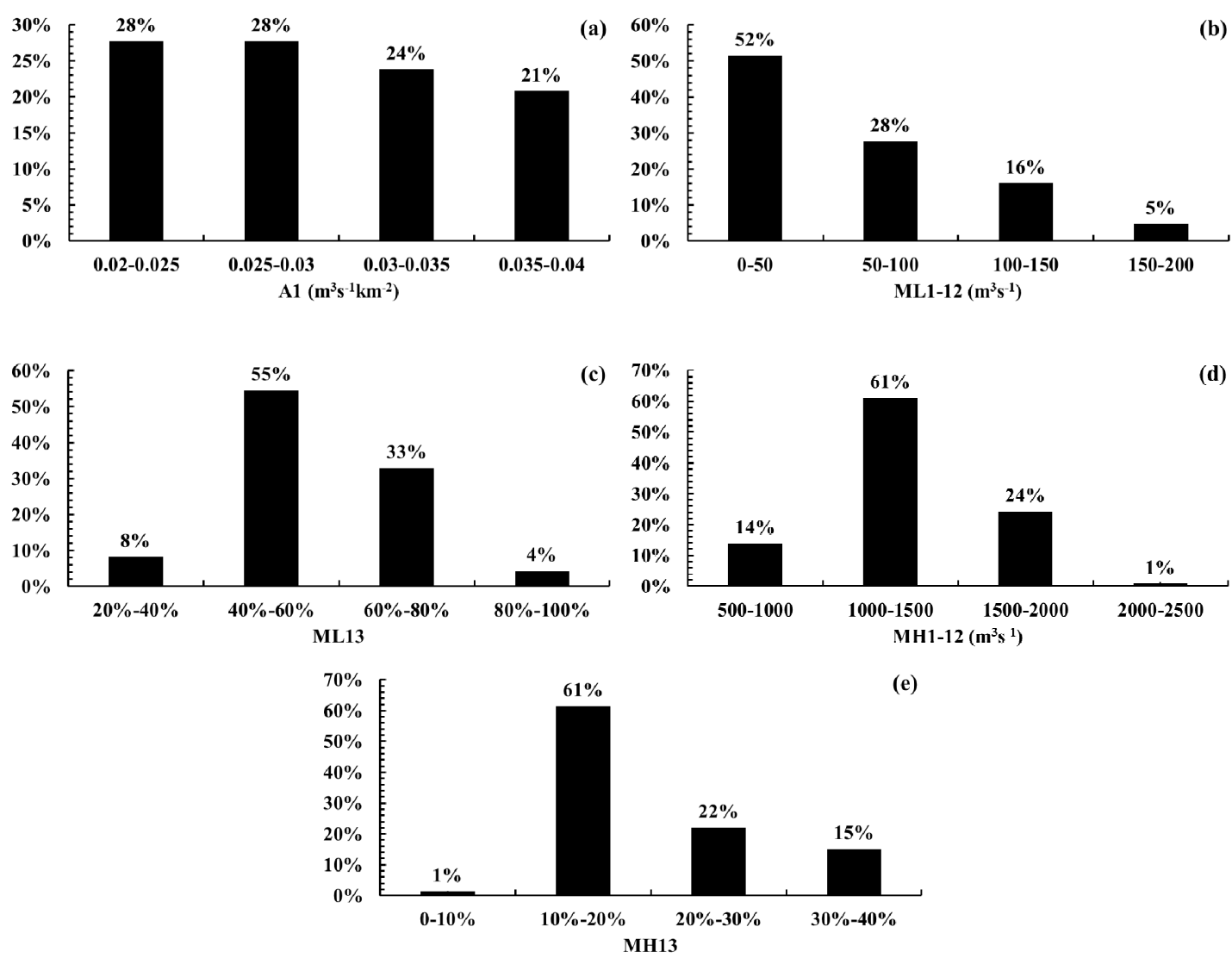

(e)

Figure 7. Hydrological signatures derived from simulations based on TRMM 3B42V7. (a) Mean annual runoff (A1); (b) mean minimum monthly flows (ML1-12); (c) mean maximum monthly flows (MH1-12); (d) variability across minimum monthly flows (ML13); (e) variability across maximum monthly flows (MH13).

Table 3. Hydrological signatures derived from observation and behavior simulations.

\begin{tabular}{|c|c|c|c|c|c|}
\hline Item & $\mathrm{A} 1\left(\mathrm{~m}^{3} \mathrm{~s}^{-1} \mathrm{~km}^{-2}\right)$ & $\operatorname{ML1-12}\left(\mathrm{m}^{3} \mathrm{~s}^{-1}\right)$ & ML13 (\%) & MH1-12 $\left(\mathrm{m}^{3} \mathrm{~s}^{-1}\right)$ & MH13 (\%) \\
\hline Observation & 0.032 & 62.4 & 9 & 1557.4 & 16 \\
\hline Upper & 0.021 & 3.1 & 30 & 752.9 & 10 \\
\hline Median & 0.029 & 46.3 & 52 & 1305.1 & 17 \\
\hline Lower & 0.040 & 166.8 & 87 & 1908.1 & 34 \\
\hline "Best" & 0.027 & 67.3 & 62 & 1204.8 & 20 \\
\hline
\end{tabular}

Figure 7a shows that the mean annual runoff under all behavior parameter sets distributed evenly. Compared to Table 3, it can be concluded that about $60 \%$ of all values were smaller than the value calculated based on observation. The mean annual runoff (A1) observation was within the 95PPU range of behavior simulations. Besides, the range was small, which indicates the simulations were quite logical.

Figure $7 \mathrm{~b}$ shows the distribution of mean minimum monthly flows. Combined with Table 3, more than three-quarters (80\%) of all values were in the range from $0 \mathrm{~m}^{3} / \mathrm{s}$ to $100 \mathrm{~m}^{3} / \mathrm{s}$, and the values of mean maximum monthly flows (ML1-12) based on observation were well-wrapped by the simulations. Figure 7c shows the distribution of variability across minimum monthly flows. Combined with Table 3 , the values of minimum monthly flows (ML13) calculated based on the observation were $9 \%$, which 
was smaller than all the values calculated based on behavior simulations. This indicates the variability of simulated low flows was higher than the observed runoff.

Figure $7 \mathrm{~d}$ shows the distribution of mean maximum monthly flows. Almost all values of MH1-12 were concentrated in the range from $500 \mathrm{~m}^{3} / \mathrm{s}$ to $2000 \mathrm{~m}^{3} / \mathrm{s}$, and the value calculated based on observation fell in the second range, which means the simulations were reasonable. Figure 7e shows the distribution of variability of maximum monthly flows. For this index, nearly all values were within the range from $10 \%$ to $40 \%$, and the dominant range was from $10 \%$ to $20 \%$. Combined with Table 3 , it is easy to know that the value of MH1-12 based on observation was right within the range of simulations.

From Table 3, almost all hydrological signatures of observation were similar to those of the "Best" parameter set, as well as median ones, which reveals that the observation was well-wrapped by the behavior simulations and the "Best" one fit well with the observation.

\section{Discussion}

In this study, the capability of reproducing proper proportions of runoff components using the hydrological model SWAT driven by TRMM precipitation data was investigated.

As mentioned in Section 2, the meteorological station was located outside the study area, which leads to the question of whether the observed precipitation was reliable or not in driving the hydrological model. Therefore, TRMM 3B42V7 was used as a precipitation alternative for hydrological simulation. In view of total runoff, TRMM 3B42V7 performed reasonably both in evaluating seasonal patterns of river flows as well as estimating total water yield on a monthly scale. TRMM 3B42V7 is regarded as qualified to reproduce observed runoff and therefore can be used to predict runoff in the future for climate change impact analysis. However, from Figure 4, deviations could still be found for some high flows, although the PBIAS of total runoff was relatively small. It is known that the SWAT model has inherent disadvantages that cause underestimation of flows $[43,44]$. One possible reason for underestimation of flow lies in its model assumption that water entering the deep aquifer is not considered in the water budget and is considered lost from the system [45]. Besides, although the percentage of glaciers in the study basin was small (less than 5\%), the model had no proper consideration for glaciers. Insufficient consideration of glaciers affects the simulation of runoff, especially in summer and autumn. Last but not least, it is well known that TRMM often underestimates precipitation in high-altitude regions [46-48]. This results in the underestimation of runoff in the study area. With increases in field observation as well as development of more accurate remote sensing data, better simulation can be derived.

As far as the authors know, there are no studies about runoff component analysis for the Niyang River Basin. However, studies within the Himalayan region, which contains the Niyang River Basin, have shown that snowmelt occupies less than $20 \%$ of total runoff $[49,50]$. From Figure 5 , it can be found that results from the behavior simulations agreed well with the conclusions derived from the studies above.

The newly developed batch-processing method helped to find all behavior parameters set, and the corresponding outputs were summarized automatically. The uncertainty from parameters was successfully propagated into runoff component simulation. However, without observed runoff component proportions, the simulations could only be indirectly testified to through total runoff and hydrological signatures comparison. More sound methods such as the use of isotope data [51] can be adopted to ensure proper modeling of different runoff components.

From Figure 5, together with the parameter values in Table 2, it can be found that temperature lapse rate (TLAPS) and snowmelt base temperature (SMTMP) were two crucial parameters that could affect the partition of snowmelt from total runoff in the study area. In the SWAT model, TLAPS was the temperature lapse rate across the watershed, and SMTMP was snowmelt base temperature, which affects the rate of snow melting. The simulations based on larger TLAPS and smaller SMTMP values resulted in larger proportions of snow. Besides, precipitation lapse rate (PLAPS), which makes corrections of precipitation before putting them into SWAT, was also crucial. The compensation effects 
of PLAPS in various sub-basins helped to offset the underestimation of TRMM data and enhance the accuracy of precipitation to improve the model performance.

Results from hydrological signatures analysis were consistent with total runoff estimation and runoff components analysis to a great extent. However, it is worth noticing that variability across minimum monthly flows calculated based on behavior simulations were higher than those based on observation, which means compared with low flow, more confidences were gained for high or normal flows.

\section{Conclusions}

This study aimed to investigate if the runoff proportions from precipitation, snowmelt, and groundwater were properly simulated using the hydrological model SWAT, driven by TRMM data from a cold, mountainous river, the Niyang River Basin, in the southwest of China.

The main conclusions of this study include: On a monthly scale, TRMM 3B42V7 had good correlations with the observed precipitation. The major sources of river flows of the Niyang River Basin were precipitation and groundwater. Snowmelt made a substantial contribution only in late spring and summer. The hydrological model driven by TRMM 3B42V7 performed well in estimating total runoff. Runoff originating from precipitation mostly concentrated in rainy seasons (May to October) and contributed more than half of total runoff through the year: Snowmelt mostly occurred in spring and summer (May to September) and contributed about $15 \%$ of total year runoff. Groundwater occupied the biggest proportion during dry seasons, and the contribution of groundwater to total runoff was about twice that of snowmelt. Based on hydrological signature analysis, though the variability of low flows was overestimated, total runoff, low, and high flows were well simulated.

The investigation of runoff proportions from precipitation, snowmelt, and groundwater in this study provided advanced understanding for hydrological modeling in cold mountainous areas. Such a study can also provide more clear and precise descriptions of runoff components to the modeling community and decision-makers.

Author Contributions: Conceptualization, W.X. and Y.-P.X.; investigation, W.X., Y.-P.X., Q.F., C.Z., and G.Q.; methodology, W.X., S.P., and Y.-P.X.; resources, Q.F., C.Z., and G.Q.; writing-original draft, W.X.; writing一review and editing, Y.-P.X.

Funding: This research was funded by the National Natural Science Foundation of China, grant number [91547106 and 51379183].

Conflicts of Interest: The authors declare no conflict of interest. The funders had no role in the design of the study; in the collection, analyses, or interpretation of data; in the writing of the manuscript; or in the decision to publish the results.

\section{References}

1. Kaygusuz, K. Hydropower as clean and renewable energy source for electricity generation. J. Eng. Res. Appl. Sci. 2016, 5, 359-369.

2. Oki, T.; Kanae, S. Global hydrological cycles and world water resources. Science 2006, 313, 1068-1072. [CrossRef] [PubMed]

3. Haddeland, I.; Heinke, J.; Biemans, H.; Eisner, S.; Flörke, M.; Hanasaki, N.; Konzmann, M.; Ludwig, F.; Masaki, Y.; Schewe, J.; et al. Global water resources affected by human interventions and climate change. Proc. Natl. Acad. Sci. USA 2014, 111, 3251-3256. [CrossRef] [PubMed]

4. Xu, X.; Lu, C.; Shi, X.; Gao, S. World water tower: An atmospheric perspective. Geophys. Res. Lett. 2008, 35, L20815. [CrossRef]

5. Xue, X.; Hong, Y.; Limaye, A.S.; Gourley, J.J.; Huffman, G.J.; Khan, S.I.; Dorji, C.; Chen, S. Statistical and hydrological evaluation of TRMM-based Multi-satellite Precipitation Analysis over the Wangchu Basin of Bhutan: Are the latest satellite precipitation products 3B42V7 ready for use in ungauged basins? J. Hydrol. 2013, 499, 91-99. [CrossRef] 
6. Huffman, G.J.; Bolvin, D.T.; Nelkin, R.J.; Wolff, D.B.; Adler, R.F.; Gu, G.; Hong, Y.; Bowan, K.P.; Stocker, E.F. The TRMM multisatellite precipitation analysis (TMPA): Quasi-global, multiyear, combined-sensor precipitation estimates at fine scales. J. Hydrometeorol. 2007, 8, 38-55. [CrossRef]

7. Joyce, R.J.; Janowiak, J.E.; Arkin, P.A.; Xie, P. CMORPH: A method that produces global precipitation estimates from passive microwave and infrared data at high spatial and temporal resolution. J. Hydrometeorol. 2004, 5, 487-503. [CrossRef]

8. Sorooshian, S.; Hsu, K.L.; Gao, X.; Gupta, H.V.; Imam, B.; Braithwaite, D. Evaluation of PERSIANN system satellite-based estimates of tropical rainfall. Bull. Am. Meteorol. Soc. 2000, 81, 2035-2046. [CrossRef]

9. Hong, Y.; Hsu, K.L.; Sorooshian, S.; Gao, X. Precipitation estimation from remotely sensed imagery using an artificial neural network cloud classification system. J. Appl. Meteorol. 2004, 43, 1834-1853. [CrossRef]

10. Moazami, S.; Golian, S.; Kavianpour, M.R.; Hong, Y. Comparison of PERSIANN and V7 TRMM Multi-satellite Precipitation Analysis (TMPA) products with rain gauge data over Iran. Int. J. Remote Sens. 2013, 34, 8156-8171. [CrossRef]

11. Yang, Y.; Luo, Y. Evaluating the performance of remote sensing precipitation products CMORPH, PERSIANN, and TMPA, in the arid region of northwest China. Theor. Appl. Climatol. 2014, 118, 429-445. [CrossRef]

12. Zhu, Q.; Xuan, W.; Liu, L.; Xu, Y.P. Evaluation and hydrological application of precipitation estimates derived from PERSIANN-CDR, TRMM 3B42V7, and NCEP-CFSR over humid regions in China. Hydrol. Process. 2016, 30, 3061-3083. [CrossRef]

13. Gupta, M.; Srivastava, P.K.; Islam, T.; Ishak, A.M.B. Evaluation of TRMM rainfall for soil moisture prediction in a subtropical climate. Environ. Earth Sci. 2014, 71, 4421-4431. [CrossRef]

14. Prasetia, R.; As-syakur, A.R.; Osawa, T. Validation of TRMM Precipitation Radar satellite data over Indonesian region. Theor. Appl. Climatol. 2013, 112, 575-587. [CrossRef]

15. Li, X.H.; Zhang, Q.; Xu, C.Y. Suitability of the TRMM satellite rainfalls in driving a distributed hydrological model for water balance computations in Xinjiang catchment, Poyang lake basin. J. Hydrol. 2012, 426, $28-38$. [CrossRef]

16. Landmann, T.; Dubovyk, O. Spatial analysis of human-induced vegetation productivity decline over eastern Africa using a decade (2001-2011) of medium resolution MODIS time-series data. Int. J. Appl. Earth Obs. Geoinf. 2014, 33, 76-82. [CrossRef]

17. Zhang, A.; Jia, G. Monitoring meteorological drought in semiarid regions using multi-sensor microwave remote sensing data. Remote Sens. Environ. 2013, 134, 12-23. [CrossRef]

18. Lang, T.J.; Barros, A.P. Winter storms in the central Himalayas. J. Meteorol. Soc. Jpn. 2004, 82, 829-844. [CrossRef]

19. Barros, A.P.; Chiao, S.; Lang, T.J.; Burbank, D.; Putkonen, J. From weather to climate-Seasonal and interannual variability of storms and implications for erosion processes in the Himalaya. Geol. Soc. Am. Spec. Pap. 2006, 398, 17-38.

20. Norris, J.; Carvalho, L.M.; Jones, C.; Cannon, F. WRF simulations of two extreme snowfall events associated with contrasting extratropical cyclones over the western and central Himalaya. J. Geophys. Res. Atmos. 2015, 120, 3114-3138. [CrossRef]

21. Weiler, M.; Seibert, J.; Stahl, K. Magic components—Why quantifying rain, snowmelt, and icemelt in river discharge is not easy. Hydrol. Process. 2018, 32, 160-166. [CrossRef]

22. Zhang, X.; Xu, Y.P.; Fu, G. Uncertainties in SWAT extreme flow simulation under climate change. J. Hydrol. 2014, 515, 205-222. [CrossRef]

23. Abbaspour, K.C.; Rouholahnejad, E.; Vaghefi, S.; Srinivasan, R.; Yang, H.; Kløve, B. A continental-scale hydrology and water quality model for Europe: Calibration and uncertainty of a high-resolution large-scale SWAT model. J. Hydrol. 2015, 524, 733-752. [CrossRef]

24. Cho, J.; Bosch, D.; Vellidis, G.; Lowrance, R.; Strickland, T. Multi-site evaluation of hydrology component of SWAT in the coastal plain of southwest Georgia. Hydrol. Process. 2013, 27, 1691-1700. [CrossRef]

25. Fuka, D.R.; Collick, A.S.; Kleinman, P.J.; Auerbach, D.; Harmel, D.; Easton, Z.M. Improving the spatial representation of soil properties and hydrology using topographically derived initialization processes in the SWAT model. Hydrol. Process. 2016, 30, 4633-4643. [CrossRef]

26. Han, H.D.; Ding, Y.J.; Liu, S.Y.; Wang, J. Regimes of runoff components on the debris-covered Koxkar glacier in western China. J. Mt. Sci. 2015, 12, 313-329. [CrossRef] 
27. Xing, B.; Liu, Z.; Liu, G.; Zhang, J. Determination of runoff components using path analysis and isotopic measurements in a glacier-covered alpine catchment (upper Hailuogou Valley) in southwest China. Hydrol. Process. 2015, 29, 3065-3073. [CrossRef]

28. Olden, J.D.; Poff, N.L. Redundancy and the choice of hydrologic indices for characterizing streamflow regimes. River Res. Appl. 2003, 19, 101-121. [CrossRef]

29. Yadav, M.; Wagener, T.; Gupta, H. Regionalization of constraints on expected watershed response behavior for improved predictions in ungauged basins. Adv. Water Res. 2007, 30, 1756-1774. [CrossRef]

30. Yilmaz, K.K.; Gupta, H.V.; Wagener, T. A process-based diagnostic approach to model evaluation: Application to the NWS distributed hydrologic model. Water Resour. Res. 2008, 44. [CrossRef]

31. Shafii, M.; Tolson, B.A. Optimizing hydrological consistency by incorporating hydrological signatures into model calibration objectives. Water Resour. Res. 2015, 51, 3796-3814. [CrossRef]

32. Yong, B.; Ren, L.L.; Hong, Y.; Wang, J.H.; Gourley, J.J.; Jiang, S.H.; Chen, X.; Wang, W. Hydrologic evaluation of Multisatellite Precipitation Analysis standard precipitation products in basins beyond its inclined latitude band: A case study in Laohahe basin, China. Water Resour. Res. 2010, 46. [CrossRef]

33. Abbaspour, K.C.; Yang, J.; Maximov, I.; Siber, R.; Bogner, K.; Mieleitner, J.; Zobrist, J.; Srinivasan, R. Modelling hydrology and water quality in the pre-alpine/alpine Thur watershed using SWAT. J. Hydrol. 2007, 333, 413-430. [CrossRef]

34. Yang, J.; Reichert, P.; Abbaspour, K.C.; Xia, J.; Yang, H. Comparing uncertainty analysis techniques for a SWAT application to the Chaohe Basin in China. J. Hydrol. 2008, 358, 1-23. [CrossRef]

35. Holvoet, K.; van Griensven, A.; Seuntjens, P.; Vanrolleghem, P.A. Sensitivity analysis for hydrology and pesticide supply towards the river in SWAT. Phys. Chem. Earth 2005, 30, 518-526. [CrossRef]

36. Winchell, M.; Srinivasan, R.; Di Luzio, M.; Arnold, J. ArcSWAT Interface for SWAT2005 User's Guide; Blackland Research and Extension Center: Temple, TX, USA, 2013; pp. 168-256.

37. Abbaspour, K.C.; Johnson, C.A.; Van Genuchten, M.T. Estimating uncertain flow and transport parameters using a sequential uncertainty fitting procedure. Vadose Zone J. 2004, 3, 1340-1352. [CrossRef]

38. Gupta, H.V.; Sorooshian, S.; Yapo, P.O. Status of automatic calibration for hydrologic models: Comparison with multilevel expert calibration. J. Hydrol. Eng. 1999, 4, 135-143. [CrossRef]

39. Moriasi, D.N.; Arnold, J.G.; Van Liew, M.W.; Bingner, R.L.; Harmel, R.D.; Veith, T.L. Model evaluation guidelines for systematic quantification of accuracy in watershed simulations. Trans. ASABE 2007, 50, 885-900. [CrossRef]

40. Nijssen, B.; Lettenmaier, D.P. Effect of precipitation sampling error on simulated hydrological fluxes and states: Anticipating the Global Precipitation Measurement satellites. J. Geophys. Res. Atmos. 2004, 109. [CrossRef]

41. Abbaspour, C.K. SWAT Calibrating and Uncertainty Programs. A User Manual; Eawag: Zurich, Switzerland, 2015; pp. 17-66.

42. Kampf, S.K.; Richer, E.E. Estimating source regions for snowmelt runoff in a Rocky Mountain basin: Tests of a data-based conceptual modeling approach. Hydrol. Process. 2014, 28, 2237-2250. [CrossRef]

43. Arnold, J.G.; Muttiah, R.S.; Srinivasan, R.; Allen, P.M. Regional estimation of base flow and groundwater recharge in the Upper Mississippi river basin. J. Hydrol. 2000, 227, 21-40. [CrossRef]

44. Qiu, L.J.; Zheng, F.L.; Yin, R.S. SWAT-based runoff and sediment simulation in a small watershed, the loessial hilly-gullied region of China: Capabilities and challenges. Int. J. Sediment. Res. 2012, 27, 226-234. [CrossRef]

45. Luo, Y.; Arnold, J.; Allen, P.; Chen, X. Baseflow simulation using SWAT model in an inland river basin in Tianshan Mountains, Northwest China. Hydrol. Earth Syst. Sci. 2012, 16, 1259-1267. [CrossRef]

46. Bharti, V.; Singh, C. Evaluation of error in TRMM 3B42V7 precipitation estimates over the Himalayan region. J. Geophy. Res. Atmos. 2015, 120, 12458-12473. [CrossRef]

47. Maussion, F.; Scherer, D.; Mölg, T.; Collier, E.; Curio, J.; Finkelnburg, R. Precipitation seasonality and variability over the Tibetan Plateau as resolved by the High Asia Reanalysis. J. Clim. 2014, 27, 1910-1927. [CrossRef]

48. The Climate Data Guide. TRMM: Tropical Rainfall Measuring Mission. Available online: https: / climatedataguide. ucar.edu/climate-data/trmm-tropical-rainfall-measuring-mission (accessed on 26 October 2018).

49. Bookhagen, B.; Burbank, D.W. Toward a complete Himalayan hydrological budget: Spatiotemporal distribution of snowmelt and rainfall and their impact on river discharge. J. Geophys. Res. Earth Surf. 2000, 115. [CrossRef] 
50. Chen, X.; Long, D.; Hong, Y.; Zeng, C.; Yan, D. Improved modeling of snow and glacier melting by a progressive two-stage calibration strategy with GRACE and multisource data: How snow and glacier meltwater contributes to the runoff of the Upper Brahmaputra River basin? Water Resour. Res. 2017, 53, 2431-2466. [CrossRef]

51. Sun, C.; Chen, Y.; Li, X.; Li, W. Analysis on the streamflow components of the typical inland river, Northwest China. Hydrol. Sci. J. 2006, 61, 970-981. [CrossRef] 